\title{
Leadership Talk by the Executive Vice-President and CEO of the European Jewish Congress
}

The European Jewish Congress (EJC), the umbrella organization of European Jewry, represents Jewish communities in 42 countries across Europe. Our communities face very diverse challenges, from security issues and attacks on fundamental freedom, to antisemitism, which comes from the far right, the far left, and from radical Islam. As such, they need a strong voice, a voice that is heard and respected, and most importantly, an effective voice. From our headquarters in Brussels, we advocate for policies and mechanisms that will hopefully have tangible effects for our communities, and we are vigilant against attacks on human dignity and democratic values.

At the core of these challenges lies the scourge of antisemitism. In all dimensions of our work, we focus on practical efforts towards combatting this evil. This is why I would like to share some of our strategies with you: Our main tool in order to achieve tangible results on the ground is advocacy. A central element of our strategy is to advocate for the development and implementation of legislation. We also identified the need for a dedicated forum to raise awareness and develop tools to fight antisemitism at the European Parliament. We succeeded in establishing the European Parliament Working Group on Antisemitism, which brings together around one hundred principled and motivated MEPs across all major political groups. ${ }^{1}$ The EJC advises the Working Group and acts currently as its Secretariat. The Working Group's groundbreaking success of 2017 was the adoption by the European Parliament of the first Resolution solely dedicated to the fight against antisemitism at EU level. The Chair of the Working Group at the time, the former Justice Minister of Spain was the legislative initiator of the Resolution. In the plenary, we found broad political support across all political the spectrum, with 76 percent of MEPs voting in favor. Through this Resolution,

1 The European Parliament Working Group on Antisemitism (WGAS) was founded in 2012 by the European Jewish Congress together with the B'nai B'rith International, who also serve as the Working Group's advisory board. The WGAS brings together members of the European Parliament at a cross-party level to improve the ways in which EU institutions contribute to combatting antisemitism. Cf. "European Parliament Working Group ON Antisemitism (WGAS)," European Jewish Congress, accessed March 18, 2019, https://eurojewcong.org/what-we-do/combattingantisemitism/ep-working-group-on-antisemitism-wgas/.

Ә OpenAccess. (c) 2019 Raya Kalenova, published by De Gruyter. (cc))BY-NC-ND This work is licensed under the Creative Commons Attribution-NonCommercial-NoDerivatives 4.0 License. 
the European Parliament reaffirmed the responsibility of society as a whole to find a solution for the problem of antisemitism and formulated a series of policy recommendations to be implemented in the Member States of the European Union. $^{2}$

This has given us considerable momentum for one more element of our strategy: Pushing for the implementation of the policy recommendations contained in the Resolution. These include the adoption and use of the IHRA Working Definition of Antisemitism, as well as increased support for security and education to combat antisemitism. In the last six months, the number of Member States who have adopted the definition has doubled. ${ }^{3}$ Adopting the definition is of course only a first step: all stakeholders must be able to use it as a point of reference for identifying antisemitism. Moreover, a priority for us is that law enforcement and the judiciary rely systematically on the Working Definition, because they need to be able to recognize antisemitic hate speech, deeds, and crimes when they occur.

An important challenge for the Jewish street is that antisemitic incidents are too often not recognized as such, and as a consequence Jewish communities feel abandoned. We were again painfully reminded of this when a court in France rejected the antisemitic character of the brutal murder of Sarah Halimi. ${ }^{4}$ Sadly, these incidents are all too common in Europe.

Although we operate mostly at the EU level, we also focus on international organizations, such as the Council of Europe and the OSCE-where the adoption of the working definition is also a priority. We also work with the respective national parliaments and governments of our affiliates.

Keeping the memory of the Shoah alive is another pillar of our advocacy work. This year we commemorated seventy-three years since the liberation of Auschwitz at the European Parliament. Since 2008, we have organized HighLevel events on International Holocaust Commemoration Day in the European

2 Cf. European Parliament, "European Parliament Resolution of 1 June 2017 on Combating antiSemitism,” accessed March 18, 2019, https://eurojewcong.org/resources/european-parliamentresolution-on-combating-anti-semitism-of-2017/.

3 Until February 2018, the Working Definition of Antisemitism has been adopted and endorsed by the United Kingdom (December 12, 2016), Israel (January 22, 2017), Austria (April 25, 2017), Scotland (April 27, 2017), Romania (May 25, 2017), Germany (September 20, 2017), Bulgaria (October 18, 2017), and Lithuania (January 24, 2017). Cf. "Working Definition of Antisemitism," International Holocaust Remembrance Alliance, issued May 26, 2016, https://www.holocaus tremembrance.com/news-archive/working-definition-antisemitism.

4 Cf., e.g., C. Valentin, "L'affaire Sarah Halimi et le tabou du "nouvel” antisémitisme," Le Figaro, July 14, 2017, http://www.lefigaro.fr/vox/societe/2017/07/14/31003-20170714ART FIG00092-l-affaire-sarah-halimi-et-le-tabou-du-nouvel-antisemitisme.php. 
Parliament and in parallel at the historical sites of the Shoah. The Shoah commemoration ceremony, initiated and organized by the EJC under the leadership of its president Moshe Kantor, has become one of the most prestigious and wellattended events within the European institutions. ${ }^{5}$ In 2018, it was adopted by the European Parliament as an official event, and this means that from now on, it will remain on the parliamentary calendar, no matter who the president is. This is the direct outcome of our efforts to raise awareness of this issue. With the rise of narratives that seek to minimize or deny the Holocaust, and with Holocaust denial still not a crime in many EU Member States, commemorating the Shoah continues to be of utmost importance. Furthermore, for two years already, we have co-organized events with the European Commission around the topics of Shoah commemoration and Shoah education, with the active participation of First Vice-President of the European Commission, Frans Timmermans. We hope that this will become a tradition and that this successful partnership will continue, and we are grateful to Katharina von Schnurbein for being essential in this partnership.

As you know, one of the main drivers of violence and harassment of Jews in Europe today is antisemitic aggression under the pretext of anti-Zionism. Therefore, there is an urgent need to educate against the notion that Jews are "fair target" for violence and harassment in the name of this so-called "political criticism" of Israel, the only Jewish state. Our approach here is to oppose the normalization of narratives that threatens our communities and to ensure that they are not given space in political discourse. For instance, Mr. Omar Barghouti, one of the founders of the BDS movement, has been invited to speak at the European Parliament by a Socialist MEP next week. Probably no other person exemplifies attempts to normalize the new antisemitism today as he does. Therefore, together with other Jewish organizations operating at the EU level, we wrote a letter to the President of the European Parliament in order to prevent Mr. Barghouti from using our democratic institutions to spread hatred. ${ }^{6}$ At the same time, the people who have been targeted by the BDS movement have the right to be heard. We bring these voices-students who were harassed, academics who were blacklisted, and businessmen whose shops were vandalized-to be heard by legislators and decision makers within the walls of the European institutions. We know the geography of Jewish communities very well and the main

5 Cf. "Shoah Commemoration,” European Jewish Congress, accessed March 18, 2019, https:// eurojewcong.org/category/ejc-in-action/shoah-commemoration/.

6 Cf., e. g., "Jewish Groups Slam Hosting of BDS Founder at European Parliament," The Times of Israel, February 18, 2018, https://www.timesofisrael.com/jewish-groups-slam-hosting-of-bdsfounder-at-european-parliament/. 
fears and challenges that they face. Whereas in Eastern Europe, communities suffer mostly from the old antisemitism, in Western Europe we face a different threat. Living in Brussels, in the heart of Europe, I think I can express our feelings about what kind of antisemitism is the most dangerous today. Therefore, I cannot finish my message without talking about radical Islam.

Last week, we commemorated the horrific murders of Ilan Halimi ${ }^{7}$ twelve years ago in France, and Dan Uzan, who three years ago gave his life protecting young children at a Bat Mitzvah in the synagogue of Copenhagen. ${ }^{8}$ Today in Europe, Jews avoid public schools, certain universities, and neighborhoods. They are often faced with a dilemma: whether to compromise their security by being publicly Jewish or to give up their freedoms and hide their Jewish identity.

We face this challenge in two interconnected ways: on the one hand, it is crucial to strengthen the security infrastructure of Jewish communities on the ground. This is the main task of our specialized office here in Vienna. ${ }^{9}$ We work closely with our communities on security and crisis management, so that they are resilient if and when the worst happens. On the other hand, not all communities receive enough support from national governments. Like all European citizens, Jews have a right to live safely and without fear. Our task is to help our affiliates' advocacy efforts in order to gain support from national governments for their security infrastructure. This has been successful. Some countries have recognized their responsibility and have begun to provide support for the security of Jewish communities. Finally, there are instances where advocacy is not successful and where other measures are required. The recent preparation of laws banning shechita, i.e., ritual slaughter, in Belgium constitute such an example. ${ }^{10}$ We supported our affiliate, the Coordinating Committee of Belgian Jew-

7 Cf. P.-A. Taguieff, “Au sein d'un conflit mondial, une bande de barbares peut s'autoriser à sacrifier un Juif...,” Le Figaro, February 24, 2006, http://www.lefigaro.fr/lefigaromagazine/2006/02/ 24/01006-20060224ARTMAG91687-au_sein_d_un_conflit_mondial_une_bande_de_barbares_ peut_s_autoriser_a_sacrifier_un_juif.php.

8 Cf. “Copenhagen shootings: Denmark buries Jewish victim Dan Uzan,” The Telegraph, February 18, 2015, https://www.telegraph.co.uk/news/worldnews/europe/denmark/11421109/Co penhagen-shootings-Denmark-buries-Jewish-victim-Dan-Uzan.html.

9 In 2012, in a major effort to enhance the security of European Jewish, the EJC launched the Security and Crisis Centre (SACC) program with its office with a Control Room in Vienna, Austria. Cf. "Protecting our Communities,” European Jewish Congress, accessed March 18, 2019, https:// eurojewcong.org/what-we-do/protecting-our-communities/.

10 Belgium plans on a complete ban of ritual slaughter to be executed in late 2018 or early 2019. Cf. "Legislation on Religious Slaughter: Factsheet," DIALREL: Encouraging Dialogue on Issues of Religious Slaughter, accessed July 28, 2018, http://www.dialrel.eu/images/factsheet-legis lation.pdf. 
ish Organizations, in bringing challenges to these unjust laws before the Belgian Constitutional Court, based on a religious freedom approach. ${ }^{11}$ In such cases, our communities take the lead, since they possess the local expertise to proceed more effectively, knowing that they have our complete support. Following recent developments in Poland, the country might be the next frontline in the fight for religious freedom, which may have disastrous consequences for the whole of Europe. ${ }^{12}$ In fact, our affiliate in Poland has already been affected by these developments.

To conclude, we hear very often these days the offensive claim that Jews have "an agenda" when talking about antisemitism. Of course we do-our agenda is to protect our communities, so that they can do their part in building a better society for all. Scholars from various fields have taken on a leading role in the academic field by providing a better understanding of antisemitism in your respective disciplines. However, a serious commitment to ending antisemitism requires a coordinated response from all actors, including government, academia, and civil society. Our message is that we need partners who understand the issue of antisemitism and are committed to finding practical solutions. We cannot do this alone, and nor should we.

Raya Kalenova is the Executive Vice-President and CEO of the European Jewish Congress (EJC). From 2008 till 2012, Raya served as Deputy Secretary General and was responsible for the creation and management of the EJC office in Brussels.

\section{Bibliography}

DIALREL: Encouraging Dialogue on Issues of Religious Slaughter. "Legislation on Religious Slaughter: Factsheet.” Accessed July 28, 2018. http://www.dialrel.eu/images/factsheetlegislation.pdf.

11 Cf. T. Zieve, "Belgian Jews File Second Lawsuit against Ban on Religious Slaughter," The Jerusalem Post, January 16, 2018, https://www.jpost.com/Diaspora/Belgian-Jews-files-second-law suit-against-ban-on-religious-slaughter-536905.

12 Cf. "President Signed the Amendment of the Act on the Institute of National Remembrance," Official Website of the President of the Republic of Poland, issued February 6, 2018, https:// www.president.pl/en/news/art,674,the-president-signed-the-amendment-of-the-act-on-the-in stitute-of-national-remembrance.html. Cf. also T. Staff, "Full Text of Poland's Controversial Holocaust Legislation,” The Times of Israel, February 1, 2018, https://www.timesofisrael.com/fulltext-of-polands-controversial-holocaust-legislation/. 
European Jewish Congress. "European Parliament Working Group ON Antisemitism (WGAS)." Accessed March 18, 2019. https://eurojewcong.org/what-we-do/combatting-anti semitism/ep-working-group-on-antisemitism-wgas/.

European Jewish Congress. "Protecting our Communities." Accessed March 18, 2019. https:// eurojewcong.org/what-we-do/protecting-our-communities/.

European Jewish Congress. "Shoah Commemoration." Accessed March 18, 2019. https://euro jewcong.org/category/ejc-in-action/shoah-commemoration/.

European Parliament. "European Parliament Resolution of 1 June 2017 on Combating anti-Semitism.” Accessed March 18, 2019. https://eurojewcong.org/resources/europeanparliament-resolution-on-combating-anti-semitism-of-2017/.

International Holocaust Remembrance Alliance. "Working Definition of Antisemitism." Issued May 26, 2016. https://www.holocaustremembrance.com/news-archive/working-defi nition-antisemitism.

N.N. “Copenhagen shootings: Denmark Buries Jewish Victim Dan Uzan.” The Telegraph, February 18, 2015. https://www.telegraph.co.uk/news/worldnews/europe/denmark/ 11421109/Copenhagen-shootings-Denmark-buries-Jewish-victim-Dan-Uzan.html.

N.N. "Full Text of Poland's Controversial Holocaust Legislation." The Times of Israel, February 1, 2018. https://www.timesofisrael.com/full-text-of-polands-controversial-holocaust-legis lation/.

N.N. "Jewish Groups Slam Hosting of BDS Founder at European Parliament." The Times of Israel, February 18, 2018. https://www.timesofisrael.com/jewish-groups-slam-hosting-ofbds-founder-at-european-parliament/.

Official Website of the President of the Republic of Poland. "President Signed the Amendment of the Act on the Institute of National Remembrance." Issued February 6, 2018. https://www.president.pl/en/news/art,674,the-president-signed-the-amendmentof-the-act-on-the-institute-of-national-remembrance.html.

Taguieff, Pierre-André. "Au sein d'un conflit mondial, une bande de barbares peut s'autoriser à sacrifier un Juif..." Le Figaro, February 24, 2006. http://www.lefigaro.fr/lefigar omagazine/2006/02/24/01006-20060224ARTMAG91687-au_sein_d_un_conflit_mondial_ une_bande_de_barbares_peut_s_autoriser_a_sacrifier_un_juif.php.

Valentin, Caroline. "L’affaire Sarah Halimi et le tabou du “nouvel” antisémitisme." Le Figaro, July 14, 2017. http://www.lefigaro.fr/vox/societe/2017/07/14/

31003-20170714ARTFIG00092-l-affaire-sarah-halimi-et-le-tabou-du-nouvel-antisemitisme. php.

Zieve, Tamara. "Belgian Jews File Second Lawsuit against Ban on Religious Slaughter." The Jerusalem Post, January 16, 2018. https://www.jpost.com/Diaspora/Belgian-Jews-files-sec ond-lawsuit-against-ban-on-religious-slaughter-536905. 